\title{
New species of the South American loxandrine genus Metoncidus Bates (Coleoptera, Carabidae)
}

\author{
Kipling W. Will ${ }^{1}$ \\ ${ }^{1}$ University of California, Dept. of ESPM - Insect Biology. Berkeley, CA 94720
}

\begin{abstract}
Resumo. Novas espécies do gênero de loxandrínio Sul-Americano, Metoncidus Bates (Coleoptera, Carabidae). Duas espécies novas são acrescentadas ao gênero, anteriormente monotípico, Metoncidus Bates, 1871 (Carabidae, Loxandrini): M. epiphytus sp. nov. (localidade-tipo Peru: Loreto, Cocha Shinguito) e M. gracilus sp. nov. (localidade-tipo Peru: Tambopata, Madre de Dios). Informações que permitem a identificação do gênero dentre outros gêneros sul-americanos de carabídeos e uma chave para espécies de Mentocidus são fornecidas.
\end{abstract}

Palavras-Chave. Amazônia; Carabidae; Loxandrini; Mentocidus; novas espécies.

Aвstract. Two species are added to the previously monotypic genus Metoncidus Bates, 1871 (Carabidae, Loxandrini): $M$. epiphytus sp. nov. (type locality Peru: Loreto, Cocha Shinguito) and M. gracilus sp. nov. (type locality Peru: Tambopata, Madre de Dios). Information allowing identification of the genus from among other South American carabid genera and a key to adult individuals of Metoncidus species are provided.

KEYwords. Amazonian; Carabidae; Loxandrini; Mentocidus; new species.

Aside from the original description (BATES 1871) of Metoncidus tenebrionides no paper discusses the characteristics of the genus except what is implied by inclusion in keys (Straneo 1977, 1979). The genus has been classified with loxandrine genera (BATES 1872), the loxandrine series (Allen \& BALl 1980) and placed among loxandrine taxa in checklists (Lorenz 1998). However, there is no mention of particular characters that support this relationship, only the mention of the similarity of general habitus noted by BATES (1871).

There are no published records for specimens outside of the single type specimen of $M$. tenebrionides. Therefore, additional specimens recently collected are a tremendous addition to our knowledge of this obscure taxon.

All methods and terms follow procedures outlined by WILL (2002). I have studied in detail, including dissection and/or detailed examination, exemplars of all genera of Loxandrini as part of an ongoing project treating the tribe as a whole. Material of Metoncidus includes only the types deposited in institutional collections noted below.

\section{Metoncidus Bates, 1871}

Metoncidus Bates, 1871:133; 1872:176; Straneo, 1977:113,116; 1979:350,353 Allen \& Ball, 1980:491; Lorenz, 1998:242.

Type species: Metoncidus tenebrionides Bates, 1871, monotypy.

Diagnosis. Separated from all other Pterostichini or pterostichine-like genera in South America by the following combination of characters: elytral plica externally evident; third elytral interval with 5-10 setae in the apical half or third; apex of ligular sclerite with 2 setae; suture between mentum and submentum entire; ventrite VI with small, shallow (nonfoveate) setigerous punctures; ventrites without sulci; tarsal claws smooth; pronotum wider than long with rounded lateral margins.

Additionally, the following characteristics are common to all species of the genus. Head with two pair of supraorbital setae. Suture between mentum and submentum present. Submentum with two pairs of lateral setae. Glossal sclerite with 2 large setae ventrally at apex. Mandibular scrobe welldefined and glabrous. Antennomere 1with large seta on dorsum, 2 glabrous, 5-11 with dense short pubescence and 46 longer setae in ring around apices. Pronotum with two pair of lateral setae. Elytra with plica well-developed apex convex, broadly rounded, basal margin entire; interval 9 with umbilicate row of 15 setae arranged in a group of 5-6 at the humeri, a group of 7-8 near the apex and 2 individual punctures distributed equidistant between these groups, intervals 2,4,6,8 glabrous. Two additional setae near apex of each elytron at apex of seventh stria. Metepimerion large, broadly rounded posteriorly. Parascutellar stria connected to stria 1. Angular basal section of stria 1 absent.

Some descriptive elements are repeated in both of the newly described species below and may be constant throughout the genus. However, these were not studied or were not available in the type specimen of M. tenebrionides.

The key to South American pterostichine genera (STRANEO 1979: 350) can be adjusted to accommodate the new species described herein by changing couplet 35 to the following: 
35(34). Elytral interval 3 with 5-10 setigerous punctures in apical half or third; pronotum wider than long, with rounded lateral margins ............ Metoncidus Bates

35. Elytral interval 3 with a single setigerous punctures near the middle; if elytral interval 3 plurisetose, then row of setae begins near elytral base and pronotum as wide as long, with lateral margins angulate 36

\section{Metoncidus tenebrionides Bates, 1871}

(Figs. $1 \mathrm{~A}, \mathrm{~B} ; 3$ )

Metoncidus tenebrionides Bates, 1871:133; Lorenz, 1998:242

Metoncidus tenebrioides [sic]; Straneo 1977: 116.

Holotype. Male. Labeled: [handwritten]"Ega"; [handwritten] "Metoncidus tenebrionides Bates"; [Red bordered disc] "Holotype". Located- Muséum National d'Histoire Naturelle, Paris (MNHN).

A brief addition to Bates' original description.

Head. Clypeus tumecent; front rather flat between eyes; clypio-frontal sulci short, deep, convergent; eyes very prominent; antennomere 1 short, stout; 2 very short, 1,2,3 subequal in length; antennae and palps pale rufous.

Thorax. Pronotum broad, quadrate, widest before middle, lateral margins slightly rounded, marginal bead thick, hind angles sub-denticulate; hind pair of lateral setae touching lateral beads; basal impressions single, linear, broad; region laterad impressions convex; anterior submarginal sulcus entire. Elytra elongate, parallel-sided, somewhat constricted behind middle (dorsal view, Fig. 1A); setigerous punctures present at base of stria 2; nine complete striae, striae 4-6 shallower toward base; all striae punctulate; stria 1 and interval 1 with 7-8 setigerous punctures in the apical half of the elytral; interval 3 with 7-9 setigerous puncture in the apical half of the elytral; interval 5 with 5-6 setigerous puncture from the basal third to the apex of the elytra; interval 7 with 2 setigerous punctures in the apical half of the elytral; interval 9 depressed toward apex. Legs paler than body.

Abdomen. Male sternum VII with two pairs of setae.

\section{Metoncidus epiphytus sp. nov.}

(Figs. 1 C, D; 2; 3)

Holotype. Female. labeled: "PERU: LORETO, Cocha Shinguito $24 \mathrm{May} 90,75^{\circ} 45^{\prime} \mathrm{W} 05^{\circ} 08^{\prime} \mathrm{S}$, Erwin et al Colls. TSn $/ 8$; insecticide fogging of Scheelea palms with epiphytes at $4 \mathrm{~m}$. ADP 67143. [red label] Holotype Metoncidus epiphytus K.Will.” Deposited United States National Museum of Natural History, Washington, DC (USNM).

Allotype. Male. Dissected with abdomen in genital vial. Labeled: “PERU: LORETO, Cmp Terry $15 \mathrm{May} 90,75^{\circ} 28^{\prime} \mathrm{W} 05^{\circ} 07^{\prime}$ S, T.L. Erwin Coll. Secondary fldplain insecticidal fog huge tree vines and epiphytes. ?P1 det.T.L.Erwin. [Red label] Allotype Metoncidus epiphytus."Deposited USNM.

Paratypes. Female. Dissected abdomen in genitalia vial. Labeled: "PERU: LORETO, Cocha Shinguito 24May90, $75^{\circ} 45^{\prime} \mathrm{W} 05^{\circ} 08^{\prime} \mathrm{S}$, Erwin et al Colls. TP/2; insecticidal fogging of big tree with vines, epiphytes tree label "FOG 1 TLE". [yellow label] Paratype Metoncidus epiphytus K.Will" . Female. Labeled: "PERU: LORETO, Cocha
Shinguito $24 \mathrm{May} 90,75^{\circ} 45^{\prime} \mathrm{W} 05^{\circ} 08^{\prime} \mathrm{S}$, Erwin et al Colls. TSn $/ 8$; insecticide fogging of Scheelea palms with epiphytes at $4 \mathrm{~m}$. ADP 67141. [yellow label] Paratype Metoncidus epiphytus K.Will." Deposited USNM.

Distribution. Peru (Fig. 3).

Diagnosis. Easily distinguished from Metoncidus gracilus sp. nov. by its larger size and more convex form (Fig. 1) and from $M$. tenebrionides by its pattern of elytral setation and basolaterally bordered pronotal margins.

Description. Larger size, overall length 9.5-9.8 mm. Color dark brunneous and integument shiny throughout body, dorsally and ventrally, elytra slightly duller, pronotum slightly iridescent. Antennae, mouthparts and legs distally very slightly paler than body. Basally, legs concolorous with ventral surface.

Head. Ocular ratio 1.5. Eyes prominent, form hemiobovate. Microsculpture on disc very shallow, reticulate microlines and sculpticells scarcely visible (evident at 50x). Frontal impressions very short, rounded. Front with slight transverse impression. Clypeus flat, smooth, clypeo-frontal suture nearly effaced. Mentum distinctly broader than long, anterior margin shallowly emarginate; epilobes prominent, short triangular. Mentum tooth blunt, emarginate at apex; mentum glabrous; paramedial pits small, deep, sharply defined. Submentum with two pairs of lateral setae. Maxillary stipes with seta near base, palpifer with setae near apex, palpomeres glabrous, fusiform, nearly equal in length. Maxillary galea fusiform with longitudinal membranous dorsal region; lacinia with thicker, curved apical digitus and medial field of finer spines and setae. Labial palpi fusiform; palpomere 2 longer than 3 , with 2 large medial setae; 2 otherwise glabrous, 3 with small scattered setae. Ligula with glossal sclerite slightly rounded at apex. Paraglossae long, free and glabrous. Labrum with 4-5 setae on apical margin, margin sinuate, slightly convex medially. Mandibular apex distinctly hooked and sharply pointed. Antennae long, extending beyond base of pronotum; antennomere 3 with 4 setae in ring at apex, antennomere 4 sparsely pubescent from midpoint to apex.

Thorax. Pronotum very shiny and slightly iridescent throughout. Microsculpture not evident except at high magnification (50x). Surface impunctate. Form quadrate, clearly broader than long, widest at or just basad middle, side margins slightly and evenly rounded to basal third and then nearly straight to hind angles, basal margin clearly emarginate between basal impressions, anterior margin with front angles only very slightly protruding, hind angles about right angled and slightly deflexed. Lateral setae arranged with one pair anterad middle, medial of lateral groove, one pair in lateral bead at hind angles. Lateral marginal bead continuous from front angles to hind angles and prolonged along base laterally, though bead less clearly defined basally than laterally. Anterior submarginal sulcus well impressed, complete. Medial longitudinal sulcus fine, sharp and broadened into a poorly defined triangular depression medially. Elytra (Fig. 1 C) parallel-sided with noticeable constriction at the midpoint; microsculpture evident 


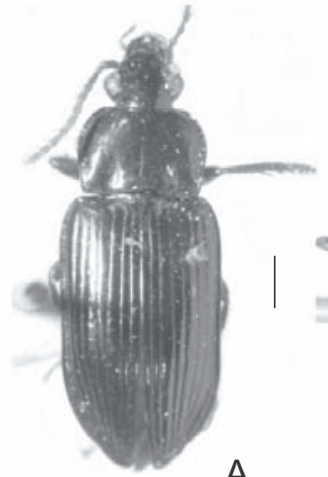

A

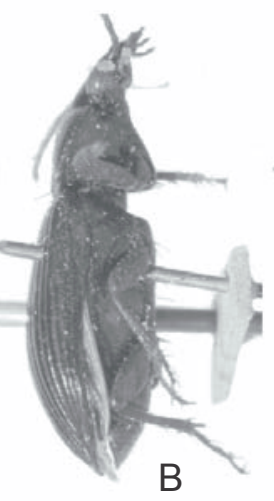

B
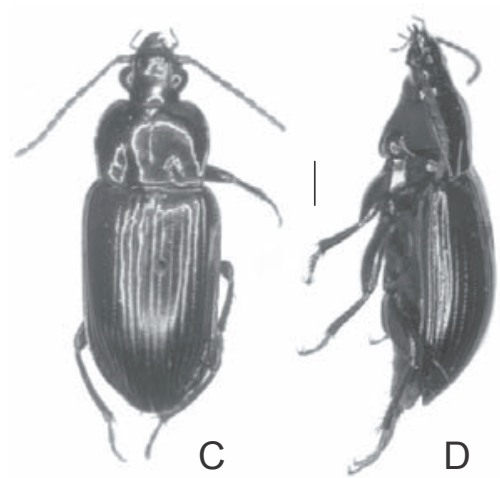
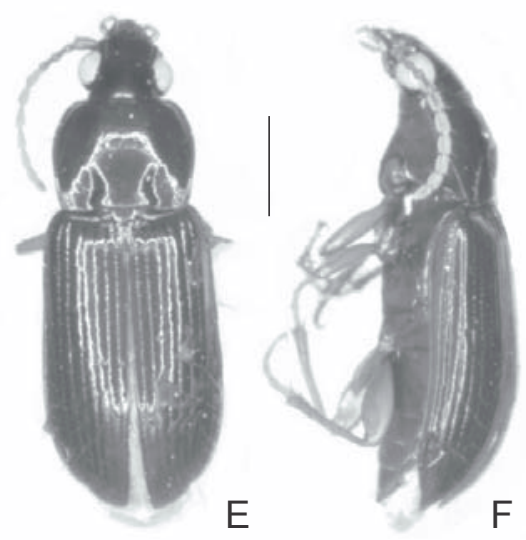

Fig. 1. Metoncidus species, dorsal and lateral views. A-B, M. tenebrionides; C-D, M. epiphytus; E-F, M. gracilus; scale bars = $1 \mathrm{~mm}$.

as an irregular network, surface slightly scabrous, somewhat shiny, not iridescent except slightly so near base. Striae deeply impressed, shallow to evanescent near base, sharply punctate, punctulae absent in apical third. Intervals slightly convex throughout; setigerous punctures as follows: 6-7 in interval 1 or touching stria $1 ; 5-10$ on interval 3 some touching stria 2 . Stria 2 slightly crenulate due to punctures. Flight wings fully developed, folded at apex. Prosternum, proepisternum and mesosternum glabrous, very shiny and iridescent. Metepisternum elongate, smooth or with 2-3 very shallowly punctures. Metasternum with a few very shallow punctures laterally. Protrochanter with medial seta. Profemur anterior face with 2-4 medial and 1 subapical setae; dorsal face with 23 setae; ventral face glabrous; posterior face with 2 setae. Protibial antennal cleaning organ well developed, with two clip setae; cleaner setal row extended dorsally, ending at larger medial seta; ventral ctenidia prominent; both proximal and distal spurs long and sharply pointed. Protarsomeres in female and meso- and metatarsomeres in both sexes, symmetrical, relatively narrow, similar in form for all legs, 1-4 ventrally with two rows of setae; $1-4$ with two apical setae, $1-2$ with additional apicomedial setae. Protarsomeres 1-3 in male tarsus broadly, symmetrically expanded with two rows of dense articulo-setae ventrally, 4 only slightly expanded with two rows of long setae. In both sexes, tarsomere 5 ventrally glabrous, dorsally with two setae, one seta at base of each claw, claws smooth. Mesocoxa with one seta mesad, one laterad. Mesotrochanter with one subapical seta. Mesofemur anterior face with basal, medial, subapical (near ventral edge) and 2-3 subdorsal setae; dorsal face with 6-8 setae in row along length, ventral face glabrous; posterior face with 1 medial seta. Mesotibia with 4 rows of stout spines and mesad row of finer, denser spines; well-developed ctenidium. Mesotarsomeres slightly more elongate than protarsomeres, 1 subequal to length of $2+3,1-2$ without shallow external sulci. Metacoxa with one seta at base near sulcus, one near apex; anterior sulcus complete, straight, appressed to anterior margin. Metatrochanter with one basal seta; metatrochanter elongate, apex conical. Metafemur anterior face with basal and medial (near ventral edge) setae; dorsal face with 2-3 setae near apex; femur otherwise glabrous. Metatibia with 4 rows of spines, medial row of finer thickness; well-developed ctenidium. Metatarsomeres elongate, 1 equal to length of $2+3,1-2$ without sulci.

Abdomen. Sterna shiny, glabrous except one pair paramedial setae on IV-VI; males and females with two pair at apex of VII. Sternum II with irregular cluster of punctures along base laterally; sternum VII apical margin smoothly rounded at apex. Male genitalia (Fig. 2 A,B). Median lobe of adeagus simple, straight, with large dorsal ostium. Female genitalia and reproductive tract (Fig. 2 C). Gonocoxite-1 with 2-3 apical setae, gonocoxite- 2 with nematiform setae in furrow, otherwise glabrous; bursa copulatrix lightly sclerotized, spermatheca with differentiated globular receptaculum at apex, appended gland attached at base of spermatheca.

\section{Metoncidus gracilus sp. nov. (Figs. 1 E, F; 3)}

Holotype. Female. labeled: "PERU: Tambopata Prov., Madre de Dios Dpto., 15km NE Puerto; Maldonado Reserva, Cuzco Amazonico, $12^{\circ} 33^{\prime} \mathrm{S}, 69^{\circ} 08^{\prime} \mathrm{W} ; 200 \mathrm{~m}$, 7 July 1989 ; J.S. Ashe, R.A. Leschen, \#445, ex., under bark; Metoncidus tenebrionides Bates [handwritten], det. George E. Ball; [red label] Holotype, Metoncidus gracilus K.Will 2003 [handwritten]". Deposited- Snow Entomological Museum, University of Kansas, Lawrence (SEMC).

Distribution. Peru (Fig. 3).

Diagnosis. Easily distinguished from Metoncidus tenebrionides and M. epiphytus sp. nov. by its much smaller size, and body form (Fig. 1). Metoncidus gracilus sp. nov. is more parallel-sided, with elytra broadly rounded at apex, and more sharply declivous posteriorly in lateral view.

Description. Medium size, overall length $6.5 \mathrm{~mm}$. Color brunneous and integument iridescent shiny throughout body, dorsally and ventrally. Legs, except coxae, maxillary and labial 


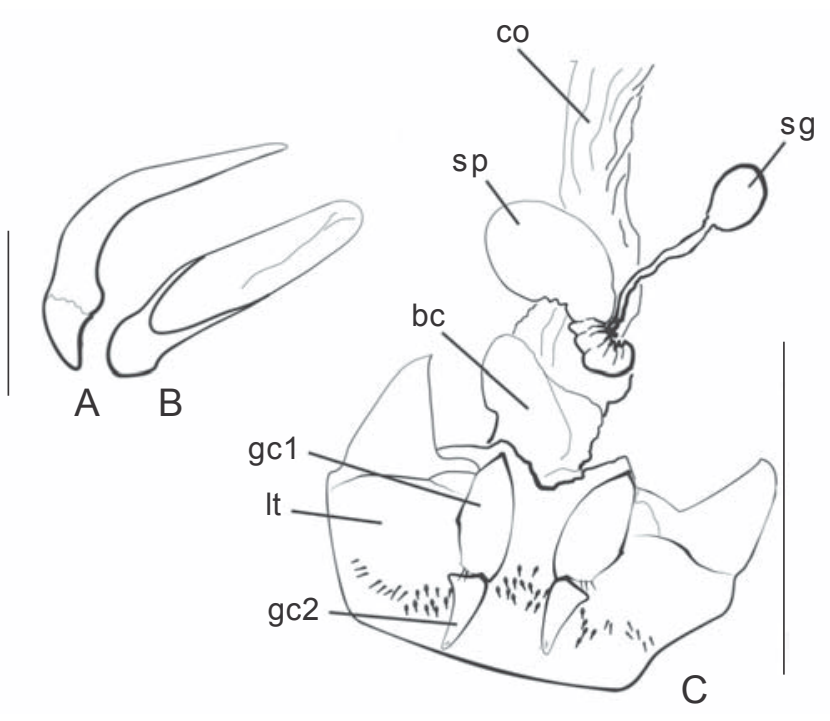

Fig. 2. Metoncidus epiphytus reproductive structures. A, median lobe of aedeagus, left lateral view; B, same, dorsal view; C, female reproductive tract and genitalia; co $=$ common oviduct; $\mathrm{sg}=$ spermathecal gland; $\mathrm{sp}=$ spermatheca; $\mathrm{bc}=$ bursa copulatrix; $\mathrm{gc} 1,2=$ gonocoxites 1,2 ; $1 \mathrm{t}=$ laterotergite IX; scale bars $=1 \mathrm{~mm}$.

palps, and antennae paler. Clypeus, mandibles and labrum slightly paler than body darker than other mouthparts.

Head. Ocular ratio 1.89. Eyes moderately prominent, large, hemispherical . Microsculpture on disc shallow, finely engraved reticulate microlines (evident at 25x). Frontal impressions very short, rounded convergent. Clypeus tumescent, clypeo-frontal suture emarginate. Mentum distinctly broader than long, anterior margin moderately emarginate; epilobes prominent, triangular. Mentum tooth blunt, slightly emarginate at apex; single pair of short, fine setae paramedially near base of mentum tooth; paramedial pits small, deep, sharply defined. Submentum with two pairs of lateral setae. Maxillary stipes with seta near base, palpifer with setae near apex, palpomeres glabrous, fusiform, nearly equal in length. Maxillary galea fusiform; lacinia with thicker, curved apical digitus and medial field of finer spines and setae. Labial palpi fusiform; palpomere 2 longer than 3 and with 2 large medial setae; otherwise glabrous. Ligula with glossal sclerite slightly rounded at apex. Paraglossae long, free and glabrous. Labrum with 4 setae on apical margin. Mandibular apex distinctly hooked and sharply pointed. Antennae long, extended beyond base of pronotum; antennomere 3 with 4 setae in ring at apex, antennomere 4 sparsely pubescent at apex.

Thorax. Pronotum very shiny and iridescent throughout. Surface impunctate. Microsculpture shallowly engraved microlines, transversely stretched but not evident except at high magnification (30x). Form quadrate, widest at or just basad middle, side margins slightly and evenly rounded to hind angles, basal margin slightly emarginate between basal impressions, anterior margin with front angles only very slightly protruding, hind angles obtuse and deflexed. Lateral setae arranged with medial pair inside lateral groove, one pair set in lateral bead at hind angles distinctly interrupting lateral margin. Lateral marginal bead continuous from front angles to hind angles, not prolonged along base, bead interrupted by lateral seta at hind angle. Anterior submarginal sulcus well impressed, nearly complete, briefly interrupted medially. Elytra (Fig. 1 E) parallel-sided with a very slight constriction at the midpoint; microsculpture not evident, very shiny and iridescent. Striae deeply impressed, shallower near base, sharply punctate, punctulae shallower in apical third, absent at apex. Striae 4-9 not extended to basal margin. Intervals convex throughout; setigerous punctures arranged as follows: interval 1 with single seta (only on left elytron), interval 3 with 5 setae, interval 5 with 4 setae, interval 7 with 2-3 setae. Flight wings evidently fully developed, visible and folded near apex of elytra. Prosternum, proepisternum and mesosturnum glabrous, very shiny and iridescent. Metepisternum elongate, impunctate. Protrochanter with medial seta. Profemur anterior face with medial and subapical setae; dorsal face with 2 setae; ventral face glabrous; posterior face with 2 setae. Protibial antennal cleaning organ well developed, two clip setae; cleaner setal row extending dorsally, ending at larger medial seta; ventral ctenidia prominent; both proximal and distal spurs long and sharply pointed. Protarsomeres in female symmetrically shaped, similar to meso- and metatarsomeres, tarsus 1 shorter than length of 2+3, tarsi 1-4 with rows of fine ventral setae mesad and laterad, 1-2 with 2 dorsoapical setae; 5 ventrally glabrous, dorsolaterally with one pair of setae. Mesocoxa with one seta mesad, one laterad. Mesotrochanter with one subapical seta. Mesofemur anterior face with medial, subapical (near ventral edge) and 2-3 subdorsal setae; dorsal face with 9-10 setae in row along length, 2-4 additional near apex; ventral face glabrous; posterior face with 1 seta near base. Mesotibia with 4 rows of stout spines and mesal row of finer, denser spines; 2 apical spurs; well-developed ctenidium. Mesotarsomeres slightly more elongate than protarsomeres, 1 subequal to length of $2+3,1-2$ with shallow external sulci, $1-4$ with two rows ventral setae; tarsomere 5 ventrally glabrous. Metacoxa with one seta at base near sulcus and one seta near apex; anterior sulcus complete, straight, appressed to anterior margin. Metatrochanter with one basal seta; metatrochanter elongate, apex conical. Metafemur anterior face with basal and medial (near ventral edge) setae; dorsal face with 2-3 setae near apex; femur otherwise glabrous. Metatibia with 4 rows of spines, medial row of finer thickness; 2 apical spurs; well-developed ctenidium. Metatarsomeres elongate, 1 equal to length of $2+3$, 1-2 with shallow external sulci, two rows ventral setae; 5 ventrally glabrous.

Abdomen. Sterna shiny, glabrous except one pair paramedial setae on IV-VI; female with two pair at apex of VII. Sternite II with irregular cluster of punctures along base laterally; sterna VII apical margin smoothly rounded at apex. Female genitalia and reproductive tract not studied. Male unknown. 


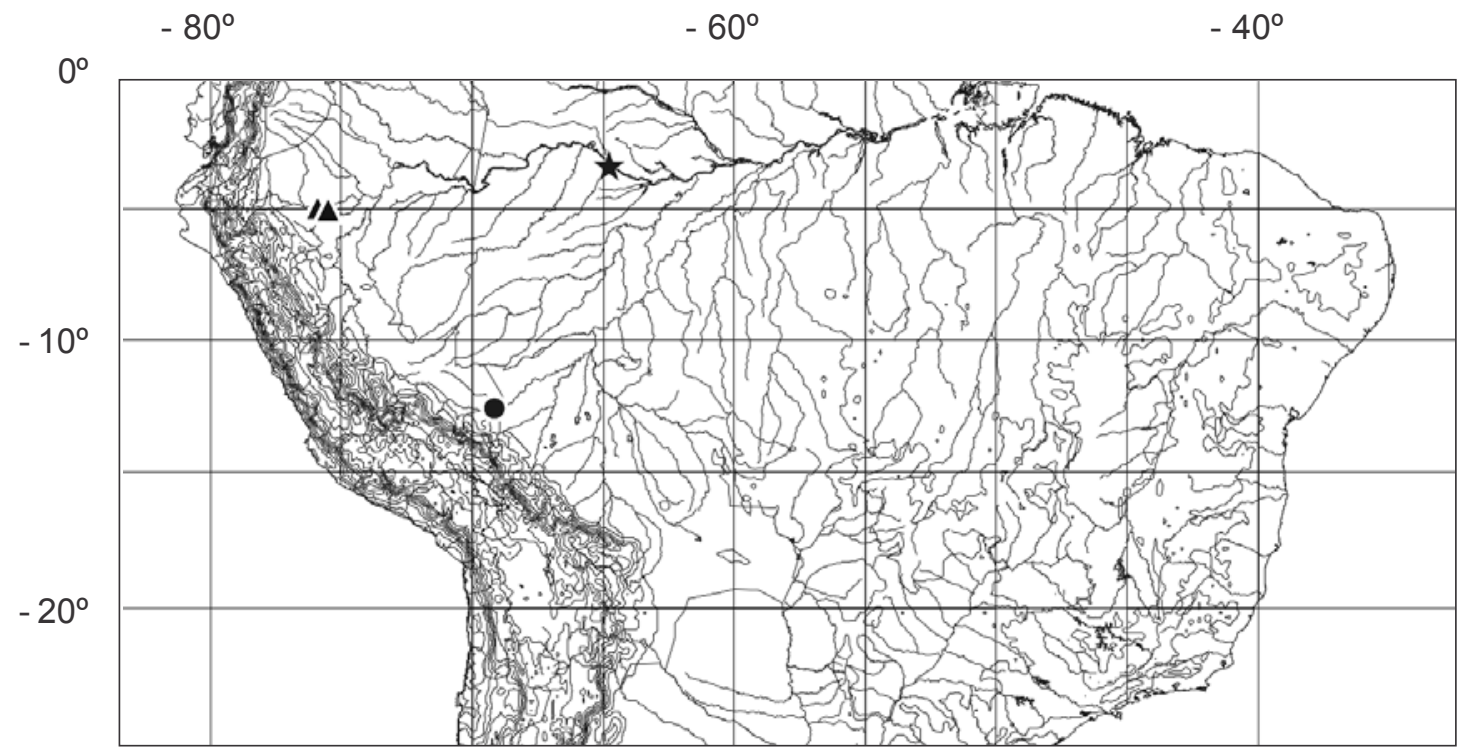

Fig. 3. Map section of South America showing sites where Metoncidus species have been collected: $*=$ M. tenebrionides; $\Delta=$ M. epiphytus; ! = M. gracilus.

Key for Metoncidus species

1. Elytral interval one with 6-8 setigerous punctures in the apical third of elytron; interval three (and in or touching stria two) with 8-10 setae in the apical third of elytron

Elytral interval one with $0-1$ setigerous punctures at the midpoint on elytron; interval three with 5 setigerous punctures in apical half of elytron

M. gracilus sp. nov.

2(1). Elytral interval five with 5-6 setigerous punctures; interval seven with 2 setigerous punctures

M. tenebrionides Bates

Elytral intervals five and seven glabrous M. epiphytus sp. nov.

\section{DISCUSSION}

Support for a monophyletic Loxandrini (ERwIN \& SiMS 1984; Bousquet \& Larochelle 1993) including Metoncidus (Loxandrus series of Allen \& BALL 1980), is limited as discussed by WILL \& LiEBHERR (1997) and WiLl et al. (2000). The phylogenetic relationships for the tribe as a whole are currently under investigation, and in that context the relationships of Metoncidus will be discussed. What if any morphological characters will prove to be synapomorphic for the tribe is presently unclear. However, as a working hypothesis, Metoncidus is best placed in Loxandrini based on the following combination of characteristics: angular basal section of stria one absent, microsculpture causing an iridescent reflex, metacoxal anterior sulcus straight and appressed to the anterior margin. Males of $M$. tenebrionides and $M$. epiphytus do not have the obliquely expanded protarsomeres found in most, but not all, males in Loxandrini.

Monophyly of this genus seems very likely given what is probably a derived body form (elongate and parallel-sided) and unusual pattern of additional setae on the elytra (plurisetose intervals), male venter (4 setae on sterna VII) and mesofemora shared by all species. None of these character states are found in putative near relatives, e.g. Loxandrus. The small number of specimens available for study, restricted to the holotype in two of the three species, prevents me from comparatively investigating potentially useful characters of the female reproductive tract and male genitalia. In the only species known from a series of specimens, $M$. epiphytus, the female tract is complete, i.e., has large obvious spermatheca very similar to putativly primitive Loxandrus species (ALLEN \& BALL 1980) such as L. omiltemi Allen \& Ball.

Little is known about the life history of these beetles. All M. epiphytus specimens were collected by insecticide fogging, and the single specimen of $M$. gracilus was found under bark. Additionally, M. gracilus was collected in "swamp forest", at a locality that was a marshy area of very low relief dominated by several large patches of Heliconia L., and surrounded by very dense growths of trees and shrubs noticeably different from those on adjacent areas of higher relief (S. J. AsHe, in litt.). One interpretation of these data is, at least for a period in the adult stadia, individuals are arboreally active. However, there are no obvious modifications of the legs or tarsomeres that could be interpreted as modifications for climbing. It is likely that when they are not on the forest floor they reside within epiphytes, pockets of debris, and aerial roots that effectively act as extensions of the forest floor. 
The range of the genus covers a large area of lowland Amazonia (Fig. 3). Given the broad separation of collecting sites across potentially suitable habitats, it seems very likely that more species of this genus await discovery.

Acknowledgments. I thank Terry Erwin (USNM) and George Ball (EH Strickland Entomological Museum, Edmonton, Alberta, Canada. UASM) for providing the specimens for this study, Thierry Deuve $(\mathrm{MNHN})$ for access and assistance during my visit and two anonymous reviewers that provided substantial comments that improved this paper.

\section{REFERENCES}

Allen, T. \& G. E. BALl. 1980. Synopsis of Mexican taxa of the Loxandrus series (Coleoptera: Carabidae: Pterostichini). Transactions of the American Entomological Society 105: 481-576.

Bates, H. W. 1871. Notes on Carabidae, and descriptions of new species (no.9). Entomologist's Monthly Magazine 9: 129-134.

Bates, H. W. 1872. Notes on Carabidae, and descriptions of new species (No.11). Entomologist's Monthly Magazine 8: 176-179.

Bousquet, Y. \& A. Larochelle. 1993. Catalogue of the Geodephaga (Coleoptera: Trachypachidae, Rhysodidae, Carabidae including Cicindelini) of America north of Mexico. Memoirs of the
Entomological Society of Canada 167: $397 \mathrm{p}$.

Erwin, T. L. \& L. L. Sims. 1984. Carabid beetles of the West Indies (Instects: Coleoptera): a synopsis of the genera and checklist of the tribes of Caraboidea, and of the West Indian species. Quaestiones Entomologicae 20(4): 351-466.

Lorenz, W. 1998. Nomina carabidarum - a directory of the scientific names of ground beetles. (Insecta, Coleoptera "Geadephaga": Trachypachidae and Carabidae incl. Paussinae, Cicindelinae, Rhysodinae). Published by the author, Hormannstrasse 4, D-82327 Tutzing, Germany.

Straneo, S. L. 1977. Chiavi per la determinazione dei generi e sottogeneri dei Pterostichini dell'America del Sud (Coleoptera Carabidae). Bollettino della Societá Entomologica Italiana 109: 104116.

Straneo, S. L. 1979. Notes about classification of the south American Pterostichini with a key for determination of subtribes, genera and subgenera (Coleoptera: Carabidae). Quaestiones Entomologicae 15: 345-356.

WILL, K. W. 2002. Revision of the new world carabiform genera Neotalus n.gen. and Abaris Dejean (Coleoptera: Carabidae: Pterostichini (Auctorum). Annals of the Carnegie Museum of Natural History 71(3): 143-213.

Will, K. W.; A. B. Attygalle \& K. Herath. 2000. New defensive chemical data for ground beetles (Coleoptera: Carabidae): interpretations in a phylogenetic framework. Biological Journal of the Linnean Society 71: 459-481.

Will, K. W. \& J. K. LiebherR. 1997. New and little known species of Loxandrus LeConte 1852 (Coleoptera:Carabidae). Studies in Neotropical Fauna and Environment 32(4): 230-238.

Received 15.XII.2003; accepted 30.VI.2004 